\title{
Uncertainty of factor $Z$ in gravimetric volume measurement
}

\author{
Mar Lar Win ${ }^{1}$ \\ ${ }^{1}$ National Institute of Metrology (Myanmar) - NIMM, Yangon, Myanmar
}

\section{ABSTRACT}

In the gravimetric volume measurement method, the factor $Z$ is generally used to facilitate an easy conversion from the apparent mass obtained using a balance to the liquid volume. The uncertainty of the measurement used for the liquid volume can be divided into two specific contributions: one from the components related to the mass measurements and one from those related to the mass-to-volume conversion. However, some ISO standards and calibration guides have suggested that the uncertainty due to the factor $Z$ is generally neglected in the uncertainty calculation pertaining to gravimetric volume measurement. This paper describes the combined effects of the density of the water, the density of the reference weights, and the air buoyancy on the uncertainty of factor $Z$ in terms of how they subsequently affect the uncertainty of the measurement results.

\section{Section: RESEARCH PAPER}

Keywords: Density of air; density of water; value of factor Z; uncertainty of factor Z; gravimetric volume measurement

Citation: Mar Lar Win, Uncertainty of factor Z in the gravimetric volume measurement, Acta IMEKO, vol. 10, no. 3, article 27, September 2021, identifier: IMEKO-ACTA-10 (2021)-03-27

Section Editor: Andy Knott, National Physical Laboratory, United Kingdom

Received: May 7, 2021; In final form: August 13, 2021; Published: September 2021

Copyright: This is an open-access article distributed under the terms of the Creative Commons Attribution 3.0 License, which permits unrestricted use, distribution, and reproduction in any medium, provided the original author and source are credited.

Corresponding author: Mar Lar Win, e-mail: marlarwin99@gmail.com

\section{INTRODUCTION}

The ISO 4787 standard describes the general equation for the calculation of the volume at the reference temperature of $20{ }^{\circ} \mathrm{C}$, $V_{20}$, from the apparent mass of the water, be it contained or delivered, as follows from [1], B.1:

$V_{20}=\left(I_{\mathrm{L}}-I_{\mathrm{E}}\right)\left(\frac{1}{\rho_{\mathrm{W}}-\rho_{\mathrm{A}}}\right)\left(1-\frac{\rho_{\mathrm{A}}}{\rho_{\mathrm{B}}}\right)[1-\gamma(t-20)]$,

where $I_{\mathrm{L}}$ is the balance reading of the vessel containing water $(\mathrm{g})$, $I_{\mathrm{E}}$ is the balance reading of empty vessel $(\mathrm{g}), \rho_{\mathrm{W}}$ is the density $(\mathrm{g} / \mathrm{mL})$ of the water at temperature $t, \rho_{\mathrm{A}}$ is the density of air $(\mathrm{g} / \mathrm{mL}), \rho_{\mathrm{B}}$ is the actual density of the reference weights $(8 \mathrm{~g} / \mathrm{mL}), \gamma$ is the coefficient of the cubic thermal expansion of the material $\left({ }^{\circ} \mathrm{C}^{-1}\right)$, and $t$ is the temperature of the water used in the testing $\left({ }^{\circ} \mathrm{C}\right)$.

Since this equation is somewhat complicated to work with, the factor $Z$ is provided to simplify the volume calculation:

$$
V_{20}=m Z[1-\gamma(t-20)],
$$

where $m$ is the net weighed values of $I_{\mathrm{L}}-I_{\mathrm{E}}$ and $Z$ is the conversion factor of the mass of the water measured in terms of volume at the measurement temperature.

\section{DETERMINATION OF FACTOR Z}

The factor $Z$ depends on the air density, water density, water temperature, and the density of the reference weights. The factor can be derived from (1) as follows:

$$
Z=\left(\frac{1}{\rho_{\mathrm{W}}-\rho_{\mathrm{A}}}\right)\left(1-\frac{\rho_{\mathrm{A}}}{\rho_{\mathrm{B}}}\right)
$$

To determine the value of factor $Z$, the following parameters must be taken into account:

- density of air $\rho_{\mathrm{A}}$ in relation to atmospheric pressure, temperature and a relative humidity of $40 \%-90 \%$;

- density of water $\rho_{\mathrm{W}}$ in relation to temperature;

- density of the reference weights $\rho_{\mathrm{B}}$ of the balance used.

\subsection{Determining the air density}

The air density $\rho_{\mathrm{A}}$ in $\mathrm{kg} \mathrm{m}^{-3}$ can be determined with sufficient uncertainty from the following CIPM approximation formula for air density [2], E.3-1:

$$
\rho_{\mathrm{A}}=\frac{0.34848 P-0.009 \mathrm{hr} \times e^{0.061 \times t}}{273.15+t},
$$

where $P$ is the atmospheric pressure $(\mathrm{hPa}), h r$ is the relative humidity $(\%)$, and $t$ is the atmospheric temperature $\left({ }^{\circ} \mathrm{C}\right)$. 
Table 1. Air density values as a function of temperature at 1,013.25 hPa and a $50 \%$ relative humidity.

\begin{tabular}{cc}
\hline Temperature in ${ }^{\circ} \mathrm{C}$ & Density of air in $\mathrm{g} / \mathrm{mL}$ \\
\hline 15 & 0.001225 \\
20 & 0.001204 \\
25 & 0.001184 \\
\hline
\end{tabular}

Table 1 presents the air density to temperature relationship at $1,013.25 \mathrm{hPa}$ and a $50 \%$ relative humidity.

\subsection{Determining the water density}

The density of air-free water $\rho_{\mathrm{W}}{ }^{\prime}$ at a pressure of $1,013.25 \mathrm{hPa}$ and a temperature $t$ between $0{ }^{\circ} \mathrm{C}$ and $40{ }^{\circ} \mathrm{C}$ expressed in terms of the ITS-90 is given by Tanaka et al. [3] as follows:

$$
\rho_{\mathrm{W}}^{\prime}=a_{5}\left[1-\frac{\left(t+a_{1}\right)^{2}\left(t+a_{2}\right)}{a_{3}\left(t+a_{4}\right)}\right],
$$

where

$$
\begin{aligned}
& a_{1}=(-3.983035 \pm 0.00067){ }^{\circ} \mathrm{C} \\
& a_{2}=301.797{ }^{\circ} \mathrm{C} \\
& a_{3}=522528.9{ }^{\circ} \mathrm{C}^{2} \\
& a_{4}=69.34881^{\circ} \mathrm{C} \\
& a_{5}=(0.999974950 \pm 0.00000084) \mathrm{g} / \mathrm{mL} \\
& t=\text { water temperature in }{ }^{\circ} \mathrm{C} .
\end{aligned}
$$

Since the pure water that is used in the laboratory is generally air-saturated, the density must be corrected. To adjust the air-free water density as described in (5) to air-saturated water between $0{ }^{\circ} \mathrm{C}$ and $25^{\circ} \mathrm{C}$ (the standard laboratory condition), we can use the following [3], 5.2:

$$
\Delta \rho=s_{0}+s_{1} \times t,
$$

where

$$
\begin{aligned}
& \frac{s_{0}}{\mathrm{~kg} \mathrm{~m}^{-3}}=-4.612 \times 10^{-3} \\
& \frac{s_{1}}{\mathrm{~kg} \mathrm{~m}^{-3}{ }^{\circ} \mathrm{C}^{-1}}=0.106 \times 10^{-3} .
\end{aligned}
$$

Moreover, since water is slightly compressible, a small correction may be required under typical laboratory conditions.

The compressibility factor $F_{\mathrm{c}}$ [3], 5.3, for the water density used at different pressures is as follows:

$F_{\mathrm{c}}=1+\left[\left(k_{0}+k_{1} t+k_{2} t^{2}\right) \Delta P\right]$,

where

$\Delta P=P-(101325 \mathrm{~Pa})$

$k_{0}=50.74 \times 10^{-11} \mathrm{~Pa}^{-1}$

$k_{1}=-0.326 \times 10^{-11} \mathrm{~Pa}^{-1}{ }^{\circ} \mathrm{C}^{-1}$

$k_{2}=0.00416 \times 10^{-11} \mathrm{~Pa}^{-1}{ }^{\circ} \mathrm{C}^{-2}$

$\rho_{\mathrm{W}}=\left(\rho_{\mathrm{W}}{ }^{\prime} \times F_{c}+\Delta \rho\right)$

with $\rho_{\mathrm{W}}=$ the density of air-saturated water and

$\rho_{\mathrm{W}}{ }^{\prime}=$ the density of air-free water.
Table 2. Water density values after correction for air-saturated distilled water.

\begin{tabular}{cccc}
\hline $\begin{array}{c}\text { Water } \\
\text { temperature } \\
\left({ }^{\circ} \mathbf{C}\right)\end{array}$ & $\begin{array}{c}\text { Air-free water } \\
\text { density }(\mathrm{g} / \mathrm{mL})\end{array}$ & $\begin{array}{c}\text { Correction for air } \\
\text { saturation } \\
(\mathrm{g} / \mathrm{mL})\end{array}$ & $\begin{array}{c}\text { Air-saturated } \\
\text { water density } \\
(\mathrm{g} / \mathrm{mL})\end{array}$ \\
\hline 15 & 0.99910257 & -0.00000302 & 0.99909955 \\
20 & 0.99820675 & -0.00000249 & 0.99820425 \\
25 & 0.99704702 & -0.00000196 & 0.99704506 \\
\hline
\end{tabular}

Table 3. Air-saturated water density as a function of water temperature and pressure.

\begin{tabular}{cccc}
\hline $\begin{array}{c}\text { Water } \\
\text { temperature } \\
\left({ }^{\circ} \mathrm{C}\right)\end{array}$ & \multicolumn{4}{c}{$\begin{array}{c}\text { Air-saturated water density }(\mathrm{g} / \mathrm{mL}) \text { at } \\
\text { atmospheric pressure of }\end{array}$} \\
\hline 15 & $\mathbf{9 0 0 \mathrm { hPa }}$ & $\mathbf{1 , 0 1 3 . 2 5} \mathrm{hPa}$ & $\mathbf{1 , 0 5 0 ~ h P a}$ \\
\hline 20 & 0.99909426 & 0.99909955 & 0.99910127 \\
25 & 0.99819907 & 0.99820425 & 0.99820594 \\
\hline
\end{tabular}

Table 2 presents examples of water density as a function of water temperature for distilled water at $1,013.25 \mathrm{hPa}$ after correction for any dissolved gasses in the water.

Meanwhile, Table 3 presents examples of calculated airsaturated water density as a function of water temperature and pressure after applying corrections for the dissolved gasses in the water.

\subsection{Density of the reference weights}

The density of the reference weights/mass pieces $\rho_{\mathrm{B}}$ that are used for the balance calibration is normally presented in the calibration certificate of the weights. Alternatively, the uncertainties corresponding to the used weight class according to OIML R 111-1 [2] can be used. If the density of the reference weights are not known, $8.0 \mathrm{~g} / \mathrm{mL}$ is generally used.

\subsection{Determining the factor $Z$ values}

The values of the conversion factor $Z(\mathrm{~mL} / \mathrm{g})$ as a function of temperature and pressure as given in the existing literature mainly pertain to distilled water. When liquids other than distilled water are used, the correction factors (factor $Z$ ) for the specific liquid must be determined.

Table 4 presents the factor $\mathrm{Z}$ values in relation to temperature and pressure. The calculations were based on (3) and (8).

\section{THE UNCERTAINTY OF FACTOR Z}

\subsection{Sources of uncertainty in factor $Z$}

Having identified the input quantities of factor $Z$ using (3), it is possible to determine the sources of uncertainty pertaining to the different input quantities, which are:

Table 4. Factor $Z$ values as a function of water temperature and pressure.

\begin{tabular}{cccc}
\hline $\begin{array}{c}\text { Water } \\
\text { temperature } \\
\left({ }^{\circ} \mathrm{C}\right)\end{array}$ & \multicolumn{3}{c}{$\begin{array}{c}\text { Value of factor } \boldsymbol{Z}(\mathrm{mL} / \mathrm{g}) \text { at } \\
\text { atmospheric pressure of }\end{array}$} \\
\hline 15 & $\mathbf{9 0 0 ~ \mathrm { hPa }}$ & $\mathbf{1 , 0 1 3 . 2 5 ~ h P a}$ & $\mathbf{1 , 0 5 0 ~} \mathrm{hPa}$ \\
\hline 20 & 1.001845 & 1.001958 & 1.001995 \\
25 & 1.002745 & 1.002858 & 1.002895 \\
27 & 1.003912 & 1.004026 & 1.004062 \\
\hline
\end{tabular}


- water density

- air density

- density of the reference weights.

The uncertainty of factor $Z$ can be determined using the GUM law of propagation of uncertainty [4] as follows:

$u(Z)=\sqrt{\left(\frac{\partial Z}{\partial \rho_{\mathrm{A}}} u\left(\rho_{\mathrm{A}}\right)\right)^{2}+\left(\frac{\partial Z}{\partial \rho_{\mathrm{W}}} u\left(\rho_{\mathrm{W}}\right)\right)^{2}+\left(\frac{\partial Z}{\partial \rho_{\mathrm{B}}} u\left(\rho_{\mathrm{B}}\right)\right)^{2}}$

where $u\left(\rho_{\mathrm{A}}\right)$ is the standard uncertainty of the air density $(\mathrm{g} / \mathrm{mL})$, $u\left(\rho_{\mathrm{W}}\right)$ is the standard uncertainty of the water density $(\mathrm{g} / \mathrm{mL})$, and $u\left(\rho_{\mathrm{B}}\right)$ is the standard uncertainty of the reference weights $(\mathrm{g} / \mathrm{mL})$.

\subsection{Uncertainty of air density}

At a relative humidity of $\mathrm{hr}=0.5(50 \%)$, a temperature of $20{ }^{\circ} \mathrm{C}$ and a pressure of $1,013.25 \mathrm{hPa}$, the uncertainty of the air density can be estimated according to OIML R111 [2], C.6.3-3, as follows:

$\frac{u\left(\rho_{\mathrm{A}}\right)}{\rho_{\mathrm{A}}}=\sqrt{\begin{array}{c}\left(1 \times 10^{-4}\right)^{2}+\left(-3.4 \times 10^{-3} \times u(t)\right)^{2} \\ +\left(1 \times 10^{-3} \times u(P)\right)^{2}+\left(-10^{-2} \times u(h r)\right)^{2}\end{array}}$,

where $u(t)$ is the uncertainty of the air temperature $t\left({ }^{\circ} \mathrm{C}\right), u(P)$ is the uncertainty of the air pressure $P(\mathrm{hPa})$, and $u(h r)$ is the uncertainty of the relative humidity $h r(\%)$.

For the uncertainty values $(k=2)$ from the calibration of the pressure, temperature and humidity sensors, the uncertainty due to the temperature of the air is $0.1^{\circ} \mathrm{C}$, the uncertainty due to the barometric pressure is $0.1 \mathrm{hPa}$, and the uncertainty due to the relative humidity is $1 \%$. This yields the following:

$$
\begin{aligned}
& u\left(\rho_{\mathrm{A}}\right)= 0.0012 \mathrm{~g} / \mathrm{mL} \\
& \times \sqrt{\left(1 \times 10^{-4}\right)^{2}+\left(-3.4 \times 10^{-3} \times \frac{0.1}{2}\right)^{2}} \\
& \sqrt{+\left(1 \times 10^{-3} \times \frac{0.1}{2}\right)^{2}+\left(-1 \times 10^{-2} \times \frac{0.01}{2}\right)^{2}} \\
&=2.52 \times 10^{-7} \mathrm{~g} / \mathrm{mL} .
\end{aligned}
$$

\subsection{Uncertainty of water density}

The uncertainty of the water density can be evaluated from the formulation given by EURAMET cg 19 [5], 7.3.3, as follows:

$u\left(\rho_{\mathrm{W}}\right)=\sqrt{u^{2}\left(\rho_{\mathrm{W}, \mathrm{F}}\right)+u^{2}\left(\rho_{\mathrm{W}, t}\right)+u^{2}\left(\delta \rho_{\mathrm{W}}\right)}$,

where

$u\left(\rho_{\mathrm{W}, t}\right)=u\left(t_{\mathrm{W}}\right) \times \beta \times \rho_{\mathrm{W}}\left(t_{\mathrm{W}}\right)$

$u\left(t_{\mathrm{W}}\right)=\left[\left(\frac{U(\text { ther })}{k}\right)^{2}+u(\text { res })^{2}\right]^{0.5}$

$u\left(t_{\mathrm{W}}\right)=\left[\left(\frac{0.01^{\circ} \mathrm{C}}{2}\right)^{2}+\left(\frac{0.01^{\circ} \mathrm{C}}{2 \sqrt{3}}\right)^{2}\right]^{0.5}$

$u\left(t_{\mathrm{W}}\right)=0.006^{\circ} \mathrm{C}$.

The expansion coefficient can be estimated as follows:

$\beta=\left(-0.1176 t^{2}+15.846 t-62.677\right) \times 10^{-6}{ }^{\circ} \mathrm{C}^{-1}$

$\beta=\left(-0.1176 \times 20^{2}+15.846 \times 20-62.677\right) \times 10^{-6}{ }^{\circ} \mathrm{C}^{-1}$

$\beta=0.00021{ }^{\circ} \mathrm{C}^{-1}$

$\rho_{\mathrm{W}}\left(t_{\mathrm{W}}\right)=0.99820425 \mathrm{~g} / \mathrm{mL}$ (from Table 3)
$u\left(\rho_{\mathrm{W}, t}\right)=0.006 \times 0.00021 \times 0.99820425$

$u\left(\rho_{\mathrm{W}, t}\right)=1.26 \times 10^{-6} \mathrm{~g} / \mathrm{mL} \sim 1 \times 10^{-6} \mathrm{~g} / \mathrm{mL}$

The standard uncertainty related to $u\left(\delta \rho_{\mathrm{W}}\right)$ could range from a few ppm for highly pure water (measured by means of a highresolution density meter) to $10 \mathrm{ppm}$ for distilled or de-ionised water, provided that the conductivity is less than $5 \mu \mathrm{S} / \mathrm{cm}$, meaning it is assumed to be $5 \times 10^{-6} \mathrm{~g} / \mathrm{mL}$.

Meanwhile, $u\left(\rho_{\mathrm{W}, \mathrm{F}}\right)$ is the estimated standard uncertainty of the formulation $\left(4.5 \times 10^{-7} \mathrm{~g} / \mathrm{mL}\right), u\left(\rho_{\mathrm{W}, t}\right)$ is the uncertainty due to the temperature of the water $\left(1 \times 10^{-6} \mathrm{~g} / \mathrm{mL}\right)$, and $u\left(\delta \rho_{\mathrm{W}}\right)$ is the uncertainty due to the purity of the water $\left(5 \times 10^{-6} \mathrm{~g} / \mathrm{mL}\right)$ [5], 8.2.3. This yields the following:

$u\left(\rho_{\mathrm{W}}\right)=\sqrt{\left(4.5 \times 10^{-7}\right)^{2}+\left(1 \times 10^{-6}\right)^{2}+\left(5 \times 10^{-6}\right)^{2}} \mathrm{~g} / \mathrm{mL}$

$=5.12 \times 10^{-6} \mathrm{~g} / \mathrm{mL}$.

\subsection{Uncertainty of the reference weights}

The uncertainty of the density of the weights/mass pieces is presented in the calibration certificate of the weights, or alternatively, according to OIML R111-1, the uncertainty of stainless-steel weights Class E2 is $140 \mathrm{~kg} / \mathrm{m}^{3}(k=2)$.

The uncertainty of the density of the reference weights is normally presented in the calibration certificate of the weights. For example, the value presented in the calibration certificate of the set of weights used is $0.06 \mathrm{~g} / \mathrm{mL}(k=2)$ :

$u\left(\rho_{\mathrm{B}}\right)=\frac{\rho_{\mathrm{r}}}{2}=\frac{0.06}{2} \mathrm{~g} / \mathrm{mL}=0.03 \mathrm{~g} / \mathrm{mL}$.

Alternatively, the uncertainty of the density of the weights, as presented in OIML R111-1, can also be used.

\subsection{Calculating the uncertainty of factor $Z$}

Table 5 presents example data for the calculation of the uncertainty of factor $Z$ for air-saturated distilled water at a temperature of $20^{\circ} \mathrm{C}$ and a barometric pressure of $1,013.25 \mathrm{hPa}$.

Sensitivity Coefficient of Air Density

$\frac{\partial Z}{\partial \rho_{\mathrm{A}}}=\left(\frac{1}{\rho_{\mathrm{W}}-\rho_{\mathrm{A}}}\right)\left(-\frac{1}{\rho_{\mathrm{B}}}\right)+\left(1-\frac{\rho_{\mathrm{A}}}{\rho_{\mathrm{B}}}\right)\left(\frac{1}{\left(\rho_{\mathrm{W}}-\rho_{\mathrm{A}}\right)^{2}}\right)$

$=0.880500 \mathrm{~mL}^{2} / \mathrm{g}^{2}$

\section{Sensitivity Coefficient of Water Density}

$\frac{\partial Z}{\partial \rho_{\mathrm{W}}}=\left(1-\frac{\rho_{\mathrm{A}}}{\rho_{\mathrm{B}}}\right)\left(\frac{-1}{\left(\rho_{\mathrm{W}}-\rho_{\mathrm{A}}\right)^{2}}\right)=-1.005876 \mathrm{~mL}^{2} / \mathrm{g}^{2}$

Sensitivity Coefficient of Density of Reference Weights

$\frac{\partial Z}{\partial \rho_{\mathrm{B}}}=\left(\frac{1}{\rho_{\mathrm{W}}-\rho_{\mathrm{A}}}\right)\left(\frac{\rho_{\mathrm{A}}}{\rho_{\mathrm{B}}{ }^{2}}\right)=1.8876 \times 10^{-5} \mathrm{~mL}^{2} / \mathrm{g}^{2}$

Table 5. Example data.

\begin{tabular}{ccc}
\hline Parameter & Value & Uncertainty $(\boldsymbol{k}=\mathbf{1})$ \\
\hline Air density & $0.001204 \mathrm{~g} / \mathrm{mL}$ & $2.52 \times 10^{-7} \mathrm{~g} / \mathrm{mL}$ \\
Water density & $0.998204 \mathrm{~g} / \mathrm{mL}$ & $5.12 \times 10^{-6} \mathrm{~g} / \mathrm{mL}$ \\
Mass density & $8.0 \mathrm{~g} / \mathrm{mL}$ & $0.03 \mathrm{~g} / \mathrm{mL}$ \\
Factor $Z$ & $1.002858 \mathrm{~mL} / \mathrm{g}$ & (Refer to the conditions in Table 4) \\
\hline
\end{tabular}


Uncertainty of Factor $Z(k=1)$

$$
\begin{aligned}
u(Z)= & \sqrt{\left(\frac{\partial Z}{\partial \rho_{\mathrm{A}}} u\left(\rho_{\mathrm{A}}\right)\right)^{2}+\left(\frac{\partial Z}{\partial \rho_{\mathrm{W}}} u\left(\rho_{\mathrm{W}}\right)\right)^{2}+\left(\frac{\partial Z}{\partial \rho_{\mathrm{B}}} u\left(\rho_{\mathrm{B}}\right)\right)^{2}} \\
= & \sqrt{\begin{array}{c}
\left(0.880500 \times 2.52 \times 10^{-7}\right)^{2} \\
+\left(-1.005876 \times 5.12 \times 10^{-6}\right)^{2} \mathrm{~mL} / \mathrm{g} \\
+\left(1.8876 \times 10^{-5} \times 0.03\right)^{2}
\end{array}} \\
= & 5.2 \times 10^{-6} \mathrm{~mL} / \mathrm{g} .
\end{aligned}
$$

\section{DISCUSSION}

As shown in Table 4 , the factor $Z$ variation in distilled water due to water temperature is approximately $2.0 \times 10^{-3} \mathrm{~mL} / \mathrm{g}$ or $2.0 \times 10^{-4} \mathrm{~mL} /\left(\mathrm{g}{ }^{\circ} \mathrm{C}\right)$ between $15^{\circ} \mathrm{C}$ and $25{ }^{\circ} \mathrm{C}$. This implies that when the uncertainty of the temperature measurement of distilled water is $0.1^{\circ} \mathrm{C}$, this will present an uncertainty of approximately $0.002 \%$ following the conversion to volume. Meanwhile, the influence of barometric pressure on the factor $Z$ is approximately $1 \times 10^{-4} \mathrm{~mL} / \mathrm{g}$ or $0.01 \%$ per pressure change of $100 \mathrm{hPa}$ between $900 \mathrm{hPa}$ and $1,050 \mathrm{hPa}$. The uncertainty of the pressure measurement in the laboratory is typically $5 \mathrm{hPa}$. This will cause the uncertainty to the conversion of volume by less than $0.0005 \%$.

\section{CONCLUSIONS}

The factor $Z$ does not only depend on the density of the liquid compensated for water temperature and pressure but also on the air density and the density of the weights used for the calibration of the balance. However, the contribution to the evaluation of uncertainty resulting from the factor $Z$ for gravimetric volume measurement is extremely small compared to that resulting from the operator process (i.e., meniscus reading) [5], 8.2.7, and the mass of water determination, provided that the measuring instruments (balance, barometer, thermometer, etc.) are used in accordance with the specifications given in the standard operating procedure (SOP). Thus, it is good practice to neglect the uncertainty of the factor $Z$ in the evaluation of uncertainty and to give only the components related to the mass measurement process [6].

\section{ACKNOWLEDGEMENT}

This paper would not have been possible without the exceptional support of Bunjob Suktat, my former expert from Physikalisch-Technische Bundesanstalt (PTB) on the 'PTBNIMM Strengthening Myanmar Quality Infrastructure Project'. His enthusiasm, knowledge, and minute attention to detail were an inspiration and ensured my work remained on track. As my teacher and mentor, he has taught me more than I could ever give him credit for here.

\section{REFERENCES}

[1] ISO 4787 (2010) - Laboratory glassware - Volumetric instruments - Methods for testing of capacity and for use.

[2] OIML R111- Weights of classes $\mathrm{E}_{1}, \mathrm{E}_{2}, \mathrm{~F}_{1}, \mathrm{~F}_{2}, \mathrm{M}_{1}, \mathrm{M}_{2}, \mathrm{M}_{3}$ Metrological and Technical Requirement, 2004.

[3] M. Tanaka, G. Girard, R. Davis, A. Peuto, N. Bignell, Recommended table for the density of water between $0{ }^{\circ} \mathrm{C}$ and $40^{\circ} \mathrm{C}$ based on recent experimental reports, Metrologia 38 (2001) pp. 301-309.

DOI: $\underline{10.1088 / 0026-1394 / 38 / 4 / 3}$

[4] JCGM 100:2008 (GUM), Evaluation of measurement data - guide to the expression of uncertainty in measurement.

[5] EURAMET cg-19, Version 3.0 (09/2018), Guidelines of determination of uncertainty in gravimetric volume calibration.

[6] ISO 8655-6:2002(E), International Standard, Piston-operated volumetric apparatus, Part 6: Gravimetric methods for the determination of measurement error. 